\title{
Kinetic modeling of carbon and nutrients removal in an integrated rotating biological contactor-activated sludge system
}

\author{
A. Akhbari - A. A. L. Zinatizadeh • \\ P. Mohammadi • Y. Mansouri • M. Irandoust • \\ M. H. Isa
}

Received: 22 May 2011/Revised: 16 October 2011/Accepted: 24 November 2011/Published online: 2 March 2012

(c) CEERS, IAU 2012

\begin{abstract}
In this study, kinetics of biological carbon, nitrogen, and phosphorous removal from a synthetic wastewater in an integrated rotating biological contactoractivated sludge system was investigated. The experimental data obtained from varying four significant independent factors viz., hydraulic retention time, chemical oxygen demand for nitrogen to phosphorus ratio, internal recirculation from aerobic to anoxic zone and disks rotating speed were used for the process kinetic modeling. In order to obtain the bioprocess kinetic coefficients, Monod, firstorder and Stover-Kincannon models were employed. As a result, Monod and Stover-Kincannon models were found
\end{abstract}

A. Akhbari

Sama Technical and Vocational Training College,

Islamic Azad University, Kermanshah Branch, Kermanshah, Iran

A. A. L. Zinatizadeh ( $\square)$

Water and Wastewater Research Center (WWRC),

Department of Applied Chemistry, Faculty of Chemistry,

Razi University, Kermanshah, Iran

e-mail: zinatizadeh@razi.ac.ir

P. Mohammadi

Department of Environmental Health Engineering-Kermanshah, Health Research Center (KHRC), Kermanshah University

of Medical Science, Kermanshah, Iran

Y. Mansouri

Young Researchers Club, Ilam Branch, Islamic Azad University,

Ilam, Iran

M. Irandoust

Department of Analytical Chemistry, Faculty of Chemistry,

Razi University, Kermanshah, Iran

M. H. Isa

Department of Civil Engineering, University Teknologi

Petronas, 31750 Tronoh, Perak, Malaysia to be the appropriate models to describe the bioprocess in the rotating biological contactor-activated sludge system as the determination coefficient for the first-order model obtained less than 0.79. According to the Monod model, growth yield, microbial decay rate, maximum specific biomass growth rate, and half-velocity constant coefficients were found to be $0.712 \mathrm{~g} \mathrm{VSS} / \mathrm{g}$ COD, $0.008 / \mathrm{d}, 5.54 / \mathrm{d}$ and $55 \mathrm{mg}$ COD/L, respectively. From Stover-Kincannon model, the maximum total substrate removal rate constant and half-velocity constant were determined as 15.2, $10.98,12.05 \mathrm{~g} / \mathrm{L} \mathrm{d}$ and $14.78,7.11,6.97 \mathrm{mg} / \mathrm{L}$ for chemical oxygen demand, nitrogen and phosphorus removal, respectively. The kinetic parameters determined in this study can be used to improve the design and operation of the biological contactor-activated sludge system in full scale.

Keywords Nutrient removal · Monod model · First order model $\cdot$ Stover-Kincannon model

$\begin{array}{ll}\text { List of symbols } \\ \text { RBC } & \text { Rotating biological contactor } \\ \text { AS } & \text { Activated sludge } \\ \text { TKN } & \text { Total Kjeldahl nitrogen, mg/L } \\ \text { MLSS } & \text { Mixed liquor suspended solids, mg/L } \\ \text { COD } & \text { Chemical oxygen demand, mg/L } \\ \text { TN } & \text { Total nitrogen, mg/L } \\ \text { VSS } & \text { Volatile suspended solid, mg/L } \\ \text { SRT } & \text { Solid retention time, } \mathrm{d}^{-1} \\ \text { OLR } & \text { Organic loading rate, } \mathrm{g} / \mathrm{L} \mathrm{d} \\ \mathrm{Y} & \text { Growth yield coefficient, } \mathrm{g} \mathrm{VSS} / \mathrm{g} \text { COD } \\ \mathrm{k}_{\mathrm{d}} & \text { Microbial decay rate, } \mathrm{d}^{-1} \\ \mu_{\mathrm{max}} & \text { Maximum specific biomass growth rate, } \mathrm{g} \text { VSS } \\ & \text { produced/g VSS present d } \\ k_{\mathrm{s}} & \text { Half-velocity constant, } \mathrm{mg} / \mathrm{m}^{3}\end{array}$




\begin{tabular}{|c|c|}
\hline$U_{\max }$ & $\begin{array}{l}\text { Maximum substrate utilization rate constant, } \\
\text { g/L d }\end{array}$ \\
\hline$r_{\mathrm{su}}$ & $\begin{array}{l}\text { Rate of change in the substrate concentration due } \\
\text { to utilization, } \mathrm{g} / \mathrm{m}^{3} \mathrm{~d}\end{array}$ \\
\hline$r_{\mathrm{g}}$ & $\begin{array}{l}\text { Rate of change in the biomass concentration, } \\
\mathrm{g} / \mathrm{m}^{3} \mathrm{~d}\end{array}$ \\
\hline$K$ & $\begin{array}{l}\text { Maximum specific substrate utilization rate, } \\
\text { g COD/g VSS prod. } d\end{array}$ \\
\hline$X$ & Biomass concentration, $\mathrm{g} / \mathrm{m}^{3}$ \\
\hline$S_{0}$ & Influent substrate concentration, $\mathrm{g} / \mathrm{m}^{3}$ \\
\hline$S$ & Substrate concentration, $\mathrm{g} / \mathrm{m}^{3}$ \\
\hline$\mu$ & $\begin{array}{l}\text { Specific biomass growth rate, g VSS produced/g } \\
\text { VSS present } d\end{array}$ \\
\hline$k_{1}$ & First-order nitrogen removal rate constant, $\mathrm{d}^{-1}$ \\
\hline$Q_{0}$ & Influent flow rates, $\mathrm{m}^{3} / \mathrm{d}$ \\
\hline$Q$ & Effluent flow rates, $\mathrm{m}^{3} / \mathrm{d}$ \\
\hline$Q_{\mathrm{w}}$ & Waste sludge flow rates, $\mathrm{m}^{3} / \mathrm{d}$ \\
\hline$X_{\mathrm{e}}$ & Effluent biomass concentration, $\mathrm{mg} / \mathrm{L}$ \\
\hline$X_{\mathrm{w}}$ & Effluent biomass concentration, $\mathrm{mg} / \mathrm{L}$ \\
\hline$V$ & Volume of the reactor, $\mathrm{m}^{3}$ \\
\hline$r_{\mathrm{su}} / x$ & Specific substrate utilization rate, g COD/g VSS d \\
\hline
\end{tabular}

\section{Introduction}

Biological carbon, nitrogen, and phosphorus removal from wastewater has become a common requirement of wastewater treatment (Brdjanovic 1998). Biological removal of nutrients $(\mathrm{N}$ and $\mathrm{P}$ ) and carbonaceous matter is often carried out by integrating anaerobic, anoxic and aerobic biological processes. Systems like $\mathrm{A} / \mathrm{O}$ and $\mathrm{A}^{2} / \mathrm{O}$ are typical examples of this integration; different treatment systems are being developed to maximize the advantages of both aerated and non-aerated processes (Santos et al. 1998). The rotating biological contactor (RBC) is widely used in wastewater treatment as an efficient attached growth system. RBCs are easy to operate, have a short start-up, require little maintenance, are effectively oxygenated with little sloughing of biomass, and have low energy consumption (Pathwardan 2003). RBCs have been used for treating domestic and industrial wastewaters, amenable to aerobic biological oxidation, for accomplishing varied degrees of carbonaceous and or nitrogenous oxygen demand reductions (Metcalf and Eddy 2003).

Process modeling can be used to describe and simulate the performance of these and other biological processes. The knowledge of process kinetics provides a rational basis for process analysis and control. It also helps to determine the effects of operational and environmental factors on substrate utilization rates. It is possible to optimize reactor performance based on kinetics study. Some commonly used models for describing organic removal in bioreactors include Monod, first order substrate removal model and StoverKincannon model (Palma and Verdone 2009). The model kinetic coefficients give the reaction rates of the system and provides a basis for reactor design and operation.

In a previous study (Akhbari et al. 2011), nutrients removal using an integrated rotating biological contactoractivated sludge (RBC-AS) system was conducted. The system was found to be effective in the removal of organic matter and nutrients. Chemical oxygen demand (COD), total nitrogen (TN) and phosphorus (TP) removals under optimized conditions was $85-87 \%, 58-74 \%$ and $58-87 \%$, respectively. This study uses the Monod, first-order kinetic, and Stover-Kincannon model to determine the COD, TN and TP removal biokinetic parameters for the RBC-AS system.

\section{Materials and methods}

Composition of synthetic wastewater (SWW)

Synthetic wastewater was prepared based on the three different COD:N:P ratios (1,000:250:50, 1,000:83.3:35 and 1,000:50:20). Glucose, $\mathrm{NH}_{4} \mathrm{Cl}$ and $\mathrm{KH}_{2} \mathrm{PO}_{4}$ were used as sources of carbon, nitrogen and phosphorus, respectively. Characteristics of the SWW are shown in Table 1.

\section{Experimental set-up}

The three-stage RBC-AS system consisted of an anaerobic $\left(\mathrm{R}_{1}\right)$, anoxic $\left(\mathrm{R}_{2}\right)$ and an aerobic reactor $\left(\mathrm{R}_{3}\right)$ made of Plexiglas. Figure 1 shows a sketch of the experimental setup (Akhbari et al. 2011). The covered anaerobic and anoxic units each had a 2.851 working volume and 12 fully immersed biodisks with $12 \mathrm{~cm}$ diameter. The biodisks were connected to a motor via a stainless steel shaft and rotated at 5-15 rpm parallel to the direction of wastewater flow. In order to supply sufficient mixing, four $2-\mathrm{cm}$ rectangular blades were placed on the disks. Two variable-

Table 1 Characteristics of synthetic wastewater

\begin{tabular}{ll}
\hline Parameter & Concentration $(\mathrm{mg} / \mathrm{L})$ \\
\hline TCOD = SCOD & $1,070-1,110$ \\
BOD & $980-1,040$ \\
TN & $65-270$ \\
TP & $20-50$ \\
$\mathrm{NO}_{3}{ }^{-}$ & $15-20$ \\
$\mathrm{NaHCO}_{3}$ & $0.5-2$ \\
\hline
\end{tabular}

Values are average of three measurements. The differences between the measurements for each were less than $1 \%$ 


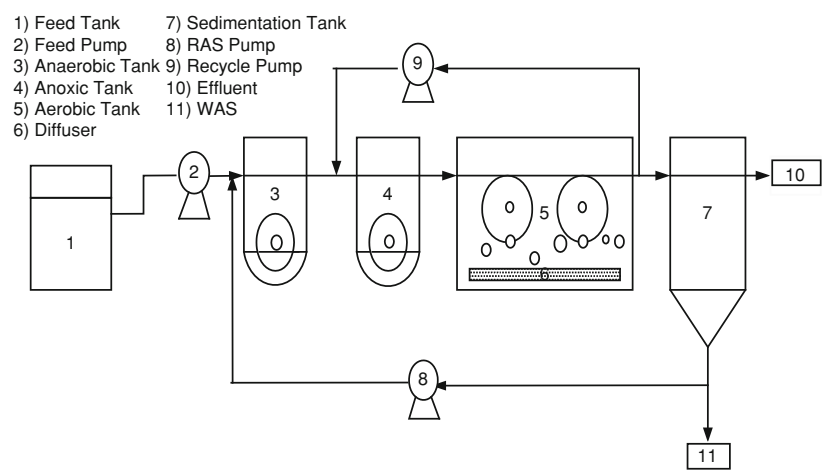

Fig. 1 Sketch of the experimental set-up (Akhbari et al. 2011)

speed peristaltic pumps were used to feed the anaerobic unit and recycle effluent from the aerobic unit to the anoxic unit in order to promote denitrification. A 6-L settling tank was provided to collect the washed out biomass for recycling to the anaerobic unit using a centrifuge pump. Excess sludge was wasted. The average dissolved oxygen (DO) levels were $0.05,0.1,5.2 \mathrm{mg} / \mathrm{L}$ in the anaerobic, anoxic and aerobic units, respectively.

\section{Bioreactor operation}

The study was conducted for a period of 10 months in 2009-2010. The reactor was initially inoculated with activated sludge taken from an aeration tank (municipal wastewater treatment plant, Kermanshah, Iran). The inoculum sludge had a sludge age of about 15 days and a mixed liquor suspended solids (MLSS) concentration of $5.8 \mathrm{~g} / \mathrm{L}$. After initial dilution, 2.5-L activated sludge was seeded to the reactor, resulting in an initial MLSS concentration of $3.8-4.0 \mathrm{~g} / \mathrm{L}$ in the reactor. The reactor start-up involved daily feeding of synthetic wastewater until biofilm started to form on the disks after 3 weeks, especially in the aerobic unit, and the reactors were thereafter operated in series in a continuous flow test mode. During the system operation period, the biomass attached to the rotating disks and suspended in the mixed liquor in the three RBC units was collected, dried, weighed and characterized for three times. Based on the measurements, the attached biomass in the anaerobic and anoxic units was found to be less than $20 \%$ of the total MLSS, while it was between 30 and $40 \%$ for the aerobic unit. The time of each experiment was dependent on the HRT and steady state was assumed after five turnovers.

\section{Analytical techniques}

The following parameters were analyzed according to the Standard Methods (APHA et al. 1999): COD, total Kjeldahl nitrogen (TKN), $\mathrm{NO}_{3}{ }^{-}, \mathrm{TP}, \mathrm{pH}, \mathrm{MLSS}$ and volatile suspended solid (VSS). For COD, spectrophotometer (DR 5000,
Hach, Jenway, USA) was used. Total Kjeldahl nitrogen was determined by TKN meter Gerhardt model (vapodest10). The dry weight of the attached biofilm per unit wetted surface area of the disk was determined by removing the attached biofilm from $1 \mathrm{~cm}^{2}$ of the disk and drying at $80^{\circ} \mathrm{C}$ for $24 \mathrm{~h}$. DO concentration in the wastewater was determined using a DO meter; WTW DO Cell OX 330, electro DO probe, Germany.

Mathematical modeling

\section{Mass balance-based (Monod) model}

For soluble substrate, the substrate utilization rate in biological systems can be modeled with the following expression (Weng and Molof 1974):

$r_{\mathrm{su}}=-\frac{\mathrm{d} s}{\mathrm{~d} t}=\frac{k S X}{K_{\mathrm{s}}+S}$

where, $K_{\mathrm{s}}$ stands for half-velocity constant.

The biomass growth rate is proportional to the substrate utilization rate by the yield coefficient, and the biomass decay is proportional to the amount of biomass present. When the substrate is being consumed at its maximum rate, the bacterial growth rate is also at its maximum (Jin and Zheng 2009). By substituting $\left(k=\mu_{\max } / Y\right)$ in Eq. (1), the expression will change to

$r_{\mathrm{su}}=\frac{\mu_{\mathrm{max}} X S}{Y\left(K_{\mathrm{s}}+S\right)}$

where $Y$ and $\mu_{\max }$ indicate growth yield and maximum specific biomass growth rate.

Taking into consideration, influent and effluent substrate concentration:

$Q_{0} S_{0}=Q S+\frac{1}{Y}\left(\frac{\mu_{\max } X S}{K_{\mathrm{s}}+S}\right) V$

and also,

$r_{\mathrm{g}}=\frac{\mathrm{d} x}{\mathrm{~d} t}=-Y\left(\frac{\mathrm{d} s}{\mathrm{~d} t}\right)-k \mathrm{~d} X=Y\left(\frac{k X S}{K_{\mathrm{s}}+S}\right)$

Dividing both sides of Eq. (4) by the biomass concentration $X$, the specific growth rate was:

$\frac{r_{\mathrm{g}}}{X}=\mu=Y\left(\frac{K_{\mathrm{s}}}{K_{\mathrm{s}}+S}\right)-k_{\mathrm{d}}$

where $K_{\mathrm{d}}$ express microbial decay rate.

The specific biomass growth rate $(\mu)$ can be defined as inverse of the solid retention time (SRT).

$\frac{1}{\mathrm{SRT}}=\left(Q-Q_{\mathrm{w}}\right) X_{\mathrm{e}}+\frac{Q_{\mathrm{w}} X_{\mathrm{w}}}{V X}$

Thus, Eq. (4) can be rearranged as follows: 


$$
\frac{1}{\mathrm{SRT}}=-Y\left(\frac{r_{\mathrm{su}}}{\mathrm{X}}\right)-k_{\mathrm{d}}=\frac{Y Q\left(S_{0}-S\right)}{V X}-k_{\mathrm{d}} .
$$

\section{First-order substrate removal model}

Assuming that first-order kinetics prevails in the reactor, the rate of change in substrate concentration in a completely mixed system could be expressed as under (Jin and Zheng 2009):

$-\frac{\mathrm{d} S}{\mathrm{~d} t}=\frac{Q S_{0}}{V}-\frac{Q S}{V}-k_{1} S$

Under pseudo steady-state conditions, the rate of change in substrate concentration $(-\mathrm{d} S / \mathrm{d} t)$ is negligible and Eq. (8) can be modified as:

$\frac{S_{0}-S}{\mathrm{HRT}}=k_{1} S$

Thus, the value of $k_{1}$ can be obtained by plotting $\left[\left(S_{0}-S\right) / \mathrm{HRT}\right]$ versus $S$.

\section{Stover-Kincannon model}

The Stover-Kincannon model was initially used to predict the attached growth biomass performance in a rotating biological contactor. Later, the model was modified and widely applied to describe and predict the performance of other types of bioreactors (Stover and Kincannon 1982; Isik and Sponza 2005; Kapdan and Aslan 2008). The original model is represented by Eq. (10).

$\frac{\mathrm{d} s}{\mathrm{~d} t}=\frac{Q}{V}\left(S_{0}-S\right)$

where $\mathrm{d} S / \mathrm{d} t$ is defined as follows:

$\frac{\mathrm{d} s}{\mathrm{~d} t}=\frac{U_{\max }\left(\frac{Q S_{0}}{V}\right)}{K_{\mathrm{s}}+\left(\frac{Q S_{0}}{V}\right)}$

$\frac{1}{\left(\frac{\mathrm{d} S}{\mathrm{~d} t}\right)}=\frac{V}{Q\left(S_{0}-S\right)}=\frac{K_{\mathrm{s}} V}{U_{\max } Q S_{0}}+\frac{1}{U_{\max }}$

If $V /\left[Q\left(S_{0}-S\right)\right]$, which is the inverse of the total substrate removal rate plotted against the inverse of the total substrate loading rate $\left(V / Q S_{0}\right)$, the kinetic constants $U_{\max }$ and $K_{\mathrm{s}}$ can be determined.

\section{Results and discussion}

Model development

\section{Mass balance-based (Monod) model}

The Monod model is the most widely used model for different reactors and wastewaters (Monod 1949; Borja et al.

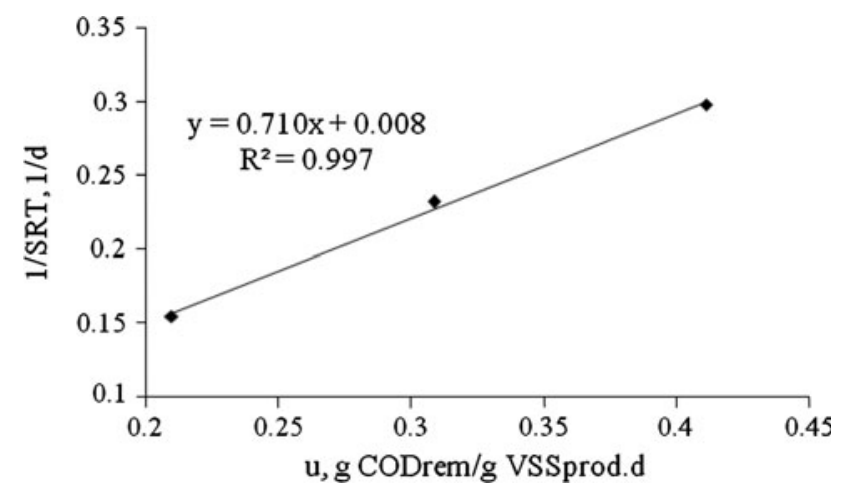

Fig. 2 Specific microbial growth rate versus specific substrate utilization rate for COD removal at influent

2003). The kinetic coefficients $\left(\mu_{\max }\right.$ and $K_{\mathrm{s}}$ ) were computed using the mass balance equation (Eq. 3) in Sigma plot Software, ver. 6. In order to estimate the biomass decay coefficient $\left(k_{\mathrm{d}}\right)$, the relationship between the inverse SRT and the specific substrate utilization rate $\left(-r_{\mathrm{su}} / X\right)$ (Eq. 7) for COD was plotted (Fig. 2). The data used for the kinetic modeling are the average of the performance data presented in Table 2 at different HRTs. All kinetic coefficients obtained from the models are summarized in Table 3. The kinetic parameters (for COD removal), $\mu_{\max }$ and $K_{\mathrm{s}}$ were obtained as $5.54 / \mathrm{d}$ and $55 \mathrm{mg} \mathrm{COD} / \mathrm{L}$, respectively. This model could not be fitted with the TN and TP data at high determination coefficient $\left(R^{2}\right)$.

\section{First-order model}

The nitrogen removal kinetics was modeled by the firstorder model. The first-order kinetic constant, $k_{1}$, was calculated by plotting $\left(\mathrm{TN}_{0}-\mathrm{TN}\right) / \mathrm{HRT}$ versus $\mathrm{TN}$ from Table 2. From Fig. 3, the kinetic coefficient $\left(k_{1}\right)$ was determined to be $1.882 / \mathrm{d}$ with the $R^{2}$ of 0.792 . The model did not show a good agreement with the data obtained for COD and $\mathrm{P}$ removal.

\section{Stover-Kincannon model}

Another model that was employed for kinetic modeling of COD, N and P removal in the RBC-AS system is the StoverKincannon model. This model is similar to the Monod model with this difference that organic loading is used instead of concentration. Figure $4 \mathrm{a}-\mathrm{c}$ shows the linearized plots obtained for each constituent (COD, $\mathrm{N}$ and $\mathrm{P}$ ). Linear regression was used to determine the intercept and slope. $k_{\mathrm{s}}$ and $U_{\max }$ for COD, $\mathrm{N}$ and P removal were calculated to be $14.78,7.11,6.97 \mathrm{mg} / \mathrm{L}$ and $15.2,10.98,12.05 \mathrm{~g} / \mathrm{L} \mathrm{d}$, respectively. The correlation coefficients for COD, N and P removal were found to be 0.813 , 0.960 , and 0.844 , respectively, confirming the applicability of the Stover-Kincannon model. 


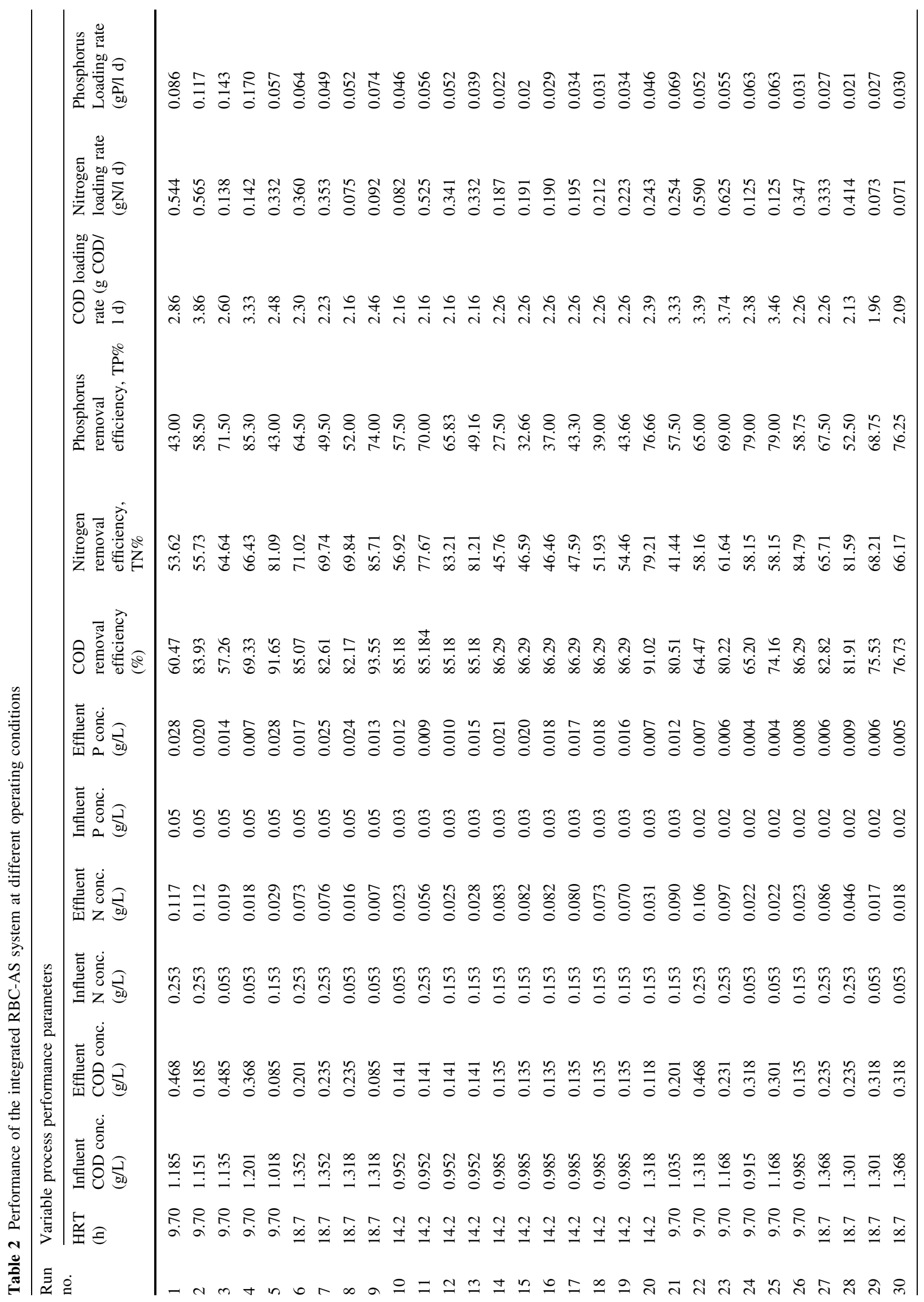


Table 3 Summary of kinetic constants obtained from the different models applied

\begin{tabular}{llllll}
\hline Kinetic models & Base for calculation & Kinetic constants & Unit & Values & $R^{2}$ \\
\hline Monod & COD & $Y$ & $\mathrm{mg} / \mathrm{mg}$ & 0.712 & 0.998 \\
& & $K_{\mathrm{s}}$ & $\mathrm{mg} \mathrm{COD} / \mathrm{l}$ & 55 & \\
& & $\mu_{\max }$ & $\mathrm{d}^{-1}$ & 5.54 & \\
& & $k_{\mathrm{d}}$ & $\mathrm{d}^{-1}$ & 0.008 & \\
First-order & Nitrogen & $k_{1}$ & $\mathrm{~d}^{-1}$ & 1.882 & 0.792 \\
Modified Stover-Kincannon & $\mathrm{COD}$ & $U_{\max }$ & $\mathrm{g} \mathrm{COD} / \mathrm{d} \mathrm{d}$ & 15.2 & 0.813 \\
& & $K_{\mathrm{s}}$ & $\mathrm{mg} \mathrm{COD} / 1$ & 14.78 & \\
& Nitrogen & $U_{\max }$ & $\mathrm{g} \mathrm{N} / 1 \mathrm{~d}$ & 10.98 & 0.96 \\
& & $K_{\mathrm{s}}$ & $\mathrm{mg} \mathrm{N} / 1$ & 7.11 & \\
& Phosphorus & $U_{\max }$ & $\mathrm{g} \mathrm{P} / \mathrm{l} \mathrm{d}$ & 12.05 & 0.844 \\
& & $K_{\mathrm{s}}$ & $\mathrm{mg} \mathrm{P} / 1$ & 6.97 & \\
\hline
\end{tabular}

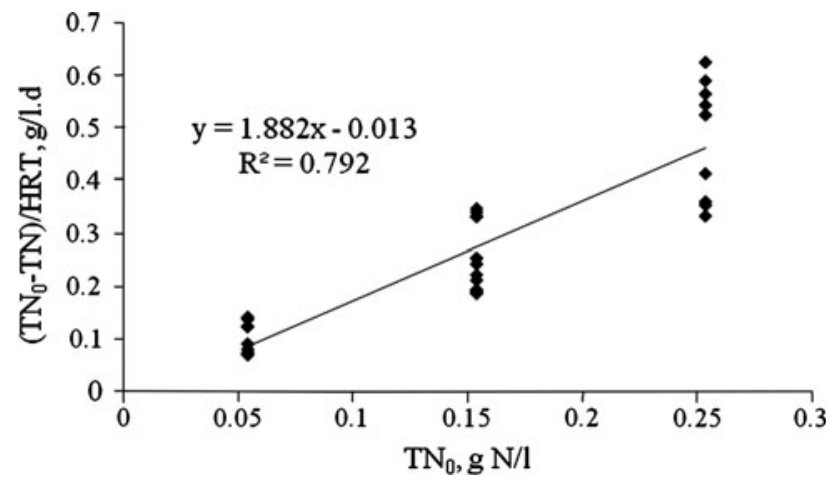

Fig. 3 First-order kinetics model plot for nitrogen removed in the integrated RBC-AS system

\section{A comparative evaluation on the kinetic models}

In this study, three kinetic models were applied to carbon and nutrients removal. Table 4 presents the kinetic constants calculated by Monod and Stover-Kincanoon model in different studies. The results demonstrated that generally $Y$ obtained from the present study was larger and the death rate constant was less than the values in literature. This might be due to the higher organic loading rate (OLR), $3.86 \mathrm{~g} \mathrm{COD} / \mathrm{L} \mathrm{d}$, applied in this study in comparison with the others (Borja et al. 2003; Jime'neza et al. 2006; Pa Pala and Bölükba 2005; Isik and Sponza 2005; Pearson et al. 1980; Sponza and Uluko 2008; Pavlostathis and Giraldo 1991; Kaewsuk et al. 2010).

Half-velocity constant is the affinity of microorganisms to the substrate. $K_{\mathrm{s}}$ can be regarded as an indicator of process efficiency; high values of the constant suggest low efficiency of the system. $K_{\mathrm{s}}$ values obtained in this study were less than those obtained in the other studies, while $\mu_{\max }$ value was larger. From Table 4, there is a decreasing trend in $Y$ as the $K_{\mathrm{s}}$ increases in different studies (Pearson et al. 1980; Pavlostathis and Giraldo 1991; Borja et al.
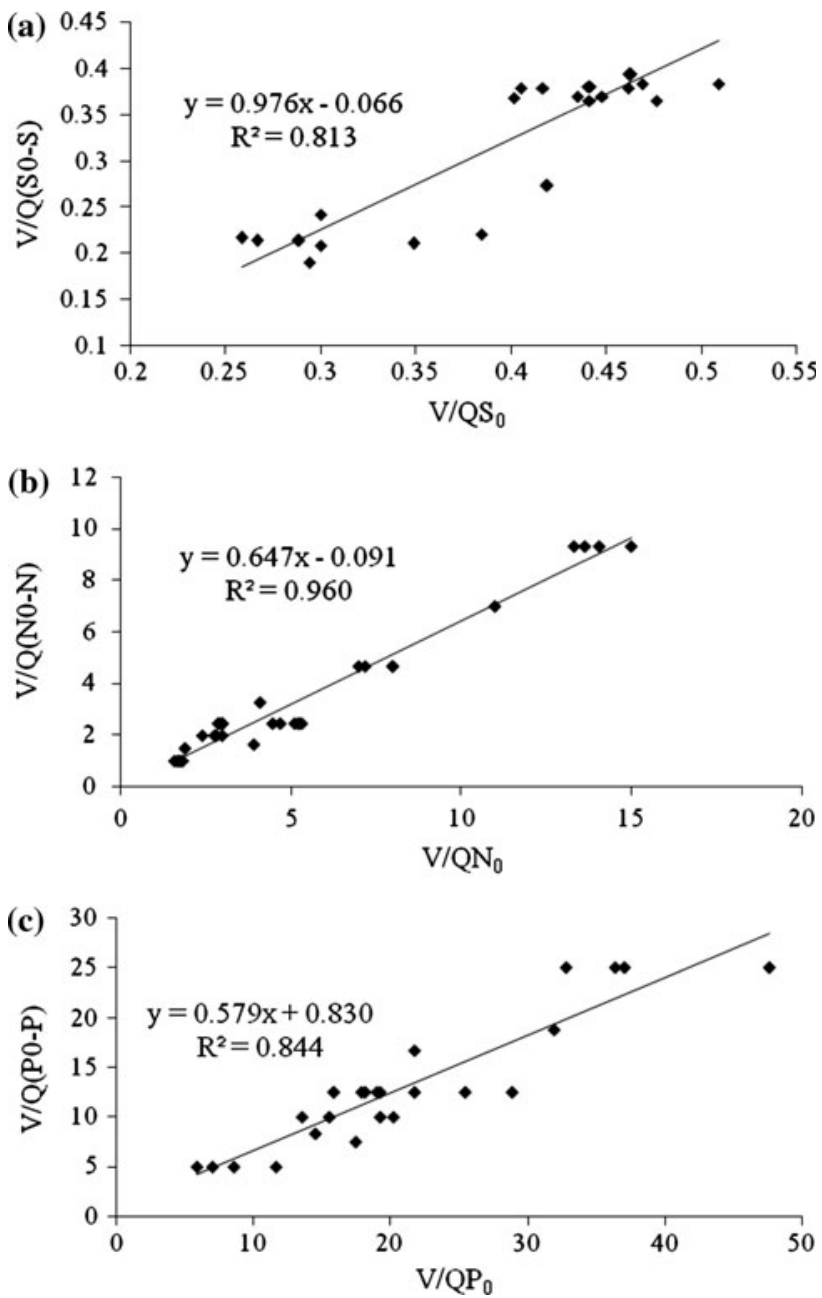

Fig. 4 Stover-Kincannon model plots for a COD, b nitrogen and c phosphorus removal in the integrated RBC-AS system

2003; Isik and Sponza 2005; Pala and Bölükba 2005; Jime'neza et al. 2006; Sponza and Uluko 2008; Kaewsuk et al. 2010). 
Table 4 Comparison of kinetic constants in the Monod and Stover-Kincanoon models cited in the literature with the present results for COD removal

\begin{tabular}{|c|c|c|c|c|c|c|c|c|}
\hline \multicolumn{4}{|c|}{ Monod constants } & \multicolumn{5}{|c|}{ Stover-Kincanoon constants } \\
\hline$\mu_{\max }\left(\mathrm{d}^{-1}\right)$ & $\begin{array}{l}K_{\mathrm{s}} \\
(\mathrm{mg} \\
\mathrm{COD} / 1)\end{array}$ & $\begin{array}{l}Y(\mathrm{mg} \\
\mathrm{VSS} / \mathrm{mg} \\
\mathrm{COD})\end{array}$ & $K_{\mathrm{d}}\left(\mathrm{d}^{-1}\right)$ & $\begin{array}{l}U_{\max } \\
(\mathrm{g} \mathrm{COD} / \\
1 \mathrm{~d})\end{array}$ & $\begin{array}{l}K_{\mathrm{S}} \\
(\mathrm{mg} / \\
\mathrm{L})\end{array}$ & $\mathrm{COD}(\mathrm{mg} / \mathrm{L})$ & Base for constant & References \\
\hline $0.3 \pm 0.03$ & - & - & $0.34 \pm 0.02$ & - & - & 34,000 & COD & Borja et al. (2003) \\
\hline $0.14 \pm 0.01$ & - & - & $0.14 \pm 0.01$ & & & 81,000 & COD & \\
\hline $0.11 \pm 0.01$ & - & - & $0.12 \pm 0.01$ & & & 113,100 & COD & \\
\hline $0.87 \pm 0.03$ & - & - & $0.9 \pm 0.04$ & - & - & 23,000 & Fermented vinasses & Jime'neza et al. (2006) \\
\hline $0.09 \pm 0.02$ & - & - & $0.13 \pm 0.09$ & & & 80,500 & Untreated vinasses & \\
\hline 1.13 & 343 & 0.7 & 0.053 & - & - & $266-800$ & COD & Jime'neza et al. (2006) \\
\hline 0.8904 & 8 & 0.6112 & 0.0047 & - & - & 3,600 & COD & $\begin{array}{l}\text { Pala and Bölükba } \\
\text { (2005) }\end{array}$ \\
\hline 0.5976 & 1.1 & 0.7875 & 0.0025 & - & - & 3,600 & COD & $\begin{array}{l}\text { Pala and Bölükba } \\
\text { (2005) }\end{array}$ \\
\hline 0.105 & $>4,000$ & 0.125 & 0.0065 & 7.501 & 8.211 & 4,214 & $\begin{array}{l}\text { Simulated cotton textile } \\
\text { wastewater }\end{array}$ & Pirsaheb et al. (2009) \\
\hline 0.60 & $12-80$ & $0.38-0.67$ & $0.01-0.14$ & - & - & - & $\mathrm{BOD}_{5}$ & Isik and Sponza (2005) \\
\hline 1.7 & $43-223$ & $0.31-0.35$ & $0.016-0.068$ & - & - & - & COD & Isik and Sponza (2005) \\
\hline 0.213 & 560.29 & 0.78 & 0.093 & 7.502 & 34.56 & 3,000 & COD & Pearson et al. (1980) \\
\hline 0.84 & $105-3,180$ & 0.125 & 0.009 & $0.77-6.67$ & 8.05 & & COD & $\begin{array}{l}\text { Sponza and Uluko } \\
\text { (2008) }\end{array}$ \\
\hline 1.69 & 174 & 0.23 & 0.14 & - & - & $1,700-4,000$ & Dairy wastewater & $\begin{array}{l}\text { Pavlostathis and } \\
\text { Giraldo-Gomez (1991) }\end{array}$ \\
\hline- & - & - & - & 83.3 & 85.5 & $7,520-11,450$ & Soybean wastewater & Kaewsuk et al. (2010) \\
\hline- & - & - & - & 83.3 & 186.23 & $2,000-15,000$ & Molasses & Yu et al. (1998) \\
\hline- & - & - & - & 12.148 & 130.28 & $1,600-9,100$ & Poultry slaughterhouse & $\begin{array}{l}\text { Büyükkamacı } \\
\text { and Filibeli (2002) }\end{array}$ \\
\hline 5.54 & 55 & 0.712 & 0.008 & 15.2 & 14.78 & 1,100 & COD & This study \\
\hline
\end{tabular}

This conforms the decrease in $\mu_{\max }$ and increase in endogenous $k_{\mathrm{d}}$. However, the kinetic constants can be maintained in the appropriate range by adjusting the effective operational and process control factors, SRT and HRT. The results showed that the modified StoverKincannon model was more applicable to predict the nitrogen removal efficiency in the RBC-AS system than the first-order model. The low correlation coefficients of the first-order model indicated that this model was not suitable for the reactor with fair degree of precision (Table 3 ).

From Eq. (12) and Fig. $4 \mathrm{~b}, K_{\mathrm{s}}$ and $U_{\max }$ were computed to be $7.11 \mathrm{~g} \mathrm{~N} / \mathrm{L}$ and $10.98 \mathrm{~g} \mathrm{~N} / \mathrm{L} \mathrm{d}$, respectively. The Stover-Kincannon model suggests that the substrate removal rate is affected by the organic loading rate entering the reactor as described in Eq. (12). The values of kinetic coefficients $\left(U_{\max }\right.$ and $K_{\mathrm{s}}$ ) were lower than those obtained in other studies as seen in Table 4 (Yu et al. 1998; Büyükkamacı and Filibeli 2002; Debik and Coskun 2009).

This could be attributed to the relatively high COD loading rate, as high as $3.86 \mathrm{~g} \mathrm{COD/L} \mathrm{d}$, applied to the bioreactor in this study. As a result, the maximum substrate utilization rate constant for $\mathrm{COD}, \mathrm{N}$ and $\mathrm{P}$ was obtained as 15.2 COD/L d, $10.98 \mathrm{~g} \mathrm{~N} / \mathrm{L} \mathrm{d}$, and $0.625 \mathrm{~g} \mathrm{P} / \mathrm{L} \mathrm{d}$, respectively, suggesting that the reactor possessed an excellent $\mathrm{COD}, \mathrm{N}$ and $\mathrm{P}$ removal capacity.

\section{Conclusion}

Kinetic analysis of the RBC-AS system was successfully performed using different kinetic models (Monod, firstorder and Stover-Kincannon) with the experimental results obtained in an earlier study (Akhbari et al. 2011). As a result, Monod and Stover-Kincannon models were found to be the appropriate models to describe the bioprocess in the RBC-AS system. According to the Monod model, $Y, k_{\mathrm{d}}$, $\mu_{\max }$, and $K_{\mathrm{s}}$ coefficients were found to be $0.712 \mathrm{~g} \mathrm{VSS} / \mathrm{g}$ COD, 0.008/d, 5.54/d and $55 \mathrm{mg}$ COD/L, respectively. The maximum substrate utilization rate constant for COD, $\mathrm{N}$ and $\mathrm{P}$ was obtained as $15.2 \mathrm{COD} / \mathrm{L} \mathrm{d}, 10.98 \mathrm{~g} \mathrm{~N} / \mathrm{L} \mathrm{d}$, $0.625 \mathrm{~g} \mathrm{P} / \mathrm{L} \mathrm{d}$, respectively, suggesting that the reactor possessed an excellent COD, $\mathrm{N}$ and $\mathrm{P}$ removal capacity. 
The kinetic parameters determined in this study can be used to improve the design and operation of the RBC-AS system on full scale.

Acknowledgments The support provided by Kermanshah Water and Wastewater Company is greatly appreciated. The authors acknowledge the access to laboratory equipment provided by the Water and Power Industry Institute for Applied and Scientific Higher Education (Mojtama-e-gharb), Kermanshah which has resulted in this paper. The authors also wish to thank Mrs S. Kiani for her assistance (Technical Assistant of Water and Wastewater Laboratory).

\section{References}

Akhbari A, Zinatizadeh AA, Mohammadi P, Irandoust M, Mansouri Y (2011) Process modeling and analysis of biological nutrients removal in an integrated RBC-AS system using response surface methodology. J Chem Eng 168:269-279

APHA, WPCF, AWWA (1999) Standard methods for the examination of water and wastewater, 20th edn. American Public Health Association (APHA), Washington, DC

Borja R, Rincón B, Raposo F, Alba J, Mart'ın A et al (2003) Kinetics of mesophilic anaerobic digestion of the two-phase olive mill solid waste. J Biochem Eng 15:139-145

Brdjanovic D (1998) Modeling of biological phosphorus removal in activated sludge systems, IHE Delft, TU Delft. Balkema Publishers, USA, $\mathrm{p} 251$

Büyükkamac1 N, Filibeli A (2002) Determination of kinetic constants of an anaerobic hybrid reactor. Process Biochem 38:73-79

Debik E, Coskun T (2009) Use of the static granular bed reactor (SGBR) with anaerobic sludge to treat poultry slaughterhouse wastewater and kinetic modeling. Biores Technol 100:2777-2782

Di Palma L, Verdone N (2009) The effect of disk rotational speed on oxygen transfer in rotating biological contactors. Biores Technol 100:1467-1470

Isik M, Sponza T (2005) Substrate removal kinetics in an upflow anaerobic sludge blanket reactor decolorising simulated textile wastewater. Process Biochem 40:1189-1198

Jime'neza AM, Borjab R, Martı'nc A, Raposob F et al (2006) Kinetic analysis of the anaerobic digestion of untreated vinasses and vinasses previously treated with Penicillium decumbens. J Environ Manag 80:303-310
Jin RC, Zheng P (2009) Kinetics of nitrogen removal in high rate anammox upflow filter. J Hazard Mater 170:652-656

Kaewsuk J, Thorasampan W, Thanuttamavong M, Tae Seo G et al (2010) Kinetic development and evaluation of membrane sequencing batch reactor (MSBR) with mixed cultures photosynthetic bacteria for dairy wastewater treatment. J Environ Manag 91:1161-1168

Kapdan IK, Aslan S (2008) Application of the Stover-Kincannon kinetic model to nitrogen removal by Chlorella vulgaris in a continuously operated immobilized photobioreactor system. J Chem Technol Biotechnol 83:998-1005

Metcalf L, Eddy H (2003) Wastewater Engineering, 4th edn. McGraw-Hill, New York

Monod J (1949) The growth of bacterial cultures. Ann Rev Microbiol 3:371-376

Pala A, Bölükba Ö (2005) Evaluation of kinetic parameters for biological CNP removal from a municipal wastewater through batch tests. Process Biochem 40:629-635

Pathwardan AW (2003) Rotating biological contactors: a review. Ind Eng Chem Res 42:2035-2051

Pavlostathis SG, Giraldo-Gomez E (1991) Kinetics of anaerobic treatment. Water Sci Technol 24(8):35-59

Pearson F, Pavlostathis SG, Giraldo E, Shiun-Chung C, Gautier M (1980) Toxic inhibition of anaerobic biodegradation. J Water Pollut Control Fed 52:472-482

Pirsaheb M, Mesdaghin AR, Shahtaheri SJ, Zinatizadeh AA (2009) Kinetic evaluation and process performance of a fixed film bioreactor removing phthalic acid and dimethyl phthalate. J Hazard Mat 167:500-506

Santos VA, Tramper J, Wijffels RH, Gewely MR (1998) Integrated nitrogen removal in compact systems by immobilized microorganisms: new-generation bioreactors. Biotechnol Annu Rev $4: 315-386$

Sponza DT, Uluko A (2008) Kinetic of carbonaceous substrate in an upflow anaerobic sludge sludge blanket (UASB) reactor treating 2,4 dichlorophenol (2,4 DCP). J Environ Manag 86:121-131

Stover EL, Kin Cannon DF (1982) Rotating biological contactor scale-up and design. In: Proceedings of the 1st International Conference on Fixed Film Biological Processes, Kings Island

Weng CN, Molof AH (1974) Nitrification in the biological fixed-film rotating disk system. J Water Pollut Control Fed 46:1675-1685

Yu HQ, Wilson F, Tay JH (1998) Kinetic analysis of an anaerobic filter treating soybean wastewater. Water Res 32:3341 